\title{
Early Detection of White Spot Syndrome Virus (WSSV) in Isolated Hemocytes of Litopenaeus vannamei
}

\author{
Ariadne Hernández-Pérez1, Rossanna Rodríguez-Canul1 ${ }^{*}$, Edgar Torres-Irineo ${ }^{2,3}$, \\ Fernando Mendoza-Cano4, Daniel Eduardo Coronado-Molina4, \\ Jesús Alejandro Zamora-Briseño ${ }^{1}$, Jorge Hernández-López ${ }^{4}$
}

\author{
${ }^{1}$ Laboratorio de Inmunología y Biología Molecular, Centro de Investigación y de Estudios Avanzados del IPN (CINVESTAV-IPN) \\ Unidad Mérida, Mérida, México \\ ${ }^{2}$ Laboratorio de Pesquerías, Centro de Investigación y de Estudios Avanzados del Instituto Politécnico Nacional-Unidad Mérida, \\ Mérida, México \\ ${ }^{3}$ UMDI-Sisal, Facultad de Ciencias, Universidad Nacional Autónoma de México, Sierra Papacal, México \\ ${ }^{4}$ Centro de Investigaciones Biológicas del Noroeste, Hermosillo, México \\ Email: ariadne.hernandez@cinvestav.mx,zambri33@hotmail.com, *rossana.rodriguez@cinvestav.mx, \\ edgar.torres82@gmail.com,Ext.5003.fmendoza@cibnor.mx, dcoronado04@cibnor.mx,jhlopez04@cibnor.mx
}

How to cite this paper: Hernández-Pérez, A., Rodríguez-Canul, R., Torres-Irineo, E., Mendoza-Cano, F., Coronado-Molina, D.E., Zamora-Briseño, J.A. and Hernández-López, J. (2017) Early Detection of White Spot Syndrome Virus (WSSV) in Isolated Hemocytes of Litopenaeus vannamei. CellBio, 6, $1-12$.

https://doi.org/10.4236/cellbio.2017.61001

Received: February 11, 2017

Accepted: March 28, 2017

Published: March 31, 2017

Copyright (c) 2017 by authors and Scientific Research Publishing Inc. This work is licensed under the Creative Commons Attribution International License (CC BY 4.0).

http://creativecommons.org/licenses/by/4.0/

\begin{abstract}
To date, White Spot Syndrome (WSS) produced by the White Spot Syndrome Virus (WSSV) causes one of the most severe diseases infecting penaeid shrimps worldwide. Although a vast amount of studies has elucidated pathogenesis in live infection models, there is still little information about the interaction of WSSV infections using in vitro models in the whiteleg shrimp Litopenaeus vannamei ( $L$. vannamei) hemocytes. In this study, a WSSV infection kinetics was performed using total hemocytes isolated from healthy $L$. vannamei organisms and maintained in in vitro conditions using isotonic solution for shrimp (ISS). The infected experimental cells received $\approx 30,000$ viral copies of WSSV. The viability of the hemocytes (control and infected group) was measured during the kinetics with trypan blue exclusion method and cells were maintained up to $6 \mathrm{hpi}$ (post-infection) with non-significant differences of viability between both groups. WSSV replication was assessed using RTPCR at the RNA expression level of the early viral gene Iel and transcripts were detected as early as $30 \mathrm{~min}$ pi. Hemocytes from WSSV group showed disrupted integrity, degranulation and irregular shape. This study provides evidence of the capability of WSSV to infect and replicates in L. vannamei hemocytes using in vitro assays in short times as $30 \mathrm{~min}$.
\end{abstract}

\section{Keywords}

WSSV, Litopenaeus vannamei, Iel Gene, Hemocytes, In Vitro Infection, GLS 
Analysis

\section{Introduction}

White Spot Syndrome Virus (WSSV) produces damaging losses to the shrimp aquaculture industry worldwide [1]. The main problem with this pathogen is the cumulative mortalities in a period of 3 to 10 days causing $100 \%$ of mortality to the industrial shrimp farming [2]. WSSV is an enveloped circular doublestranded DNA virus with a bacillar shape. The virions are $275 \mathrm{~nm}$ in length, and $83 \mathrm{~nm}$ in diameter and the size of the nucleocapsid is $216 \mathrm{~nm}$ in length and 54 $\mathrm{nm}$ in diameter [3]. It has been established that WSSV primarily infects tissue cells of ectodermal and mesodermal origin and its target tissues are hematopoietic, epithelial and connective tissues [4] [5] [6]. Hemocytes from crustaceans are categorized into three main groups, hyaline cells, semigranular cells and granular cell and they are considered the analogue cells of lymphocytes from vertebrates [7]. They derive from mesoderm tissues [8] and are considered the effector cells of the crustacean's immune system because they are actively involved in processes such as pathogen recognition, phagocytosis, melanization, cytotoxicity and cellular communication [9]. The circulatory system in crustaceans is incompletely closed and the hemolymph irrigates all the tissues [10], therefore, hemocytes could play an important role for the dispersion of the WSSV virions through the organism. However, to date, it is still not clear whether WSSV is able to replicate within these cells, especially in the hemocytes of the whiteleg shrimp $L$. vannamei, the most cultivated shrimp worldwide.

In the crayfish Procambarus clarkii the expression of Ie genes was detected with cycloheximide (CHX) treated primary culture of $P$. clarkii hemocytes, suggesting that WSSV replication occurs in these cells [11]. In contrast, a recent study reported that WSSV replicates in hematopoietic cells of $P$. clarkii, but this process was not entirely successful in hemocytes [12]. Likewise, it was reported that WSSV infects mainly hyaline hemocytes, and granular cells are less susceptible to the virus in Pacifastacus leniusculus [5], which lead to the conclusion that hyaline cells were the target cells of WSSV in P. leniusculus. To date, these findings have been commonly accepted as part of the pathogenesis of WSSV infection in other crustacean's species.

The culture of hemocytes could help in the evaluation of the mechanisms associated with the host-parasite infections [13]-[18]. However, due to the variability in methodologies and reagents used, this strategy is not entirely feasible yet [18]. This could be solved by implementing the use of non-expensive reagents for the detection of early stages of WSSV infection in target cells.

The aims of this study were i) to confirm if the WSSV is capable of replicating in the hemocytes of $L$. vannamei and ii) to evaluate the use of an isotonic solution for shrimp (ISS) to maintain the viability of $L$. vannamei hemocytes under 
these conditions.

\section{Materials and Methods}

\subsection{Hemolymph Donors}

Healthy juvenile shrimps ( $L$. vannamei) $(12.72 \pm 0.83 \mathrm{~g}$ of weight and $11.98 \pm$ $1.29 \mathrm{~cm}$ in length), were purchased from a local farm in Sonora, Mexico, and acclimatized in the laboratory for ten days with constant aeration at 35 practical salinity units (PSU). Tanks were cleaned daily, and water was changed at $20 \%$ of its total volume. Shrimp were fed ad libitum, twice a day with commercial food (35\% protein). Before the experiments, they were screened to be free of WSSV, IHHNV, TSV, YHV, and IMNV using IQ2000 kits, following the manufacturer's instructions with qPCR or RT-PCR, depending on the case.

\subsection{WSSV Inoculum Preparation and Viral Load Quantification}

\subsubsection{Inoculum Preparation}

The inoculum was prepared from gills, pleopods, and muscle of $L$. vannamei infected with WSSV. Tissues were disrupted with a tissue homogenizer with $4 \mathrm{ml}$ of saline solution $(150 \mathrm{mM} \mathrm{NaCl})$ and centrifuged at $3000 \times g$ for $20 \mathrm{~min}$ at $4{ }^{\circ} \mathrm{C}$. The supernatant was filtered through a $0.22 \mu \mathrm{M}$ pore size membrane and centrifuged in a micro-filter Millipore Sigma Amicon ${ }^{\circledR}$ of $100 \mathrm{kDa}$ cut-off [19]. The material retained in the filter was collected and kept frozen at $-80^{\circ} \mathrm{C}$, until its use.

\subsubsection{Inoculum's Viral Load Quantification}

The inoculum's viral load was quantified by qPCR. DNA was extracted using the Geneclean ${ }^{\circledR}$ kit (MP Biomedicals), and the copy number was quantified with a commercial qPCR kit (IQ REAL ${ }^{\mathrm{TM}}$ WSSV Quantitative System) following the manufacturer's instructions. Calibration curve included $10^{1}, 10^{2}, 10^{3}, 10^{4}$ and $10^{5}$ WSSV copies/ $\mu \mathrm{L}$, and was recorded using a Corbett thermocycler. Data were processed with the Rotor-Gene Software Version 6.1.

\subsubsection{Inoculum's Infectivity Evaluation Viral Load Quantification}

The pathogenicity of the WSSV inoculum was corroborated in five shrimps $L$. vannamei injected with $50 \mu \mathrm{L}$ of the inoculums between the third and fourth abdominal segment. After $24 \mathrm{hpi}$, hemolymph was collected from the ventral sinus of each shrimp with a $1 \mathrm{ml}$ syringe, containing the ISS in 1:3 ratio [20]. This solution is composed of $450 \mathrm{mM} \mathrm{NaCl}, \mathrm{KCl} 10 \mathrm{mM}$, and $10 \mathrm{mM}$ HEPES, with $\mathrm{pH}$ adjusted to $7.5 \pm 0.2$ and osmolarity to $903 \pm 13 \mathrm{mOsmol} \mathrm{kg}{ }^{-1}$ to mimic hemolymph characteristics. Additionally, to avoid coagulation and cellular activation, EDTA $10 \mathrm{mM}$ was added to the ISS. The hemocytes were separated from the hemolymph after centrifugation with $1000 \times g$ for $5 \mathrm{~min}$ and $4^{\circ} \mathrm{C}$. The supernatant was discarded, and the cell pellet was re-suspended gently with $50 \mu \mathrm{L}$ of ISS without EDTA in order to avoid interference with subsequent molecular analyses. Then, DNA from hemocytes was extracted with the Geneclean ${ }^{\circledR}$ kit 
(MP Biomedicals). The presence of WSSV was detected by PCR using the IQ SYBR $^{\circledR}$ green super mix kit (Biorad) and the primers Iel-F (5 '-GAC-TCT-ACA-AAT-CTC-TTT-GCC-A-3') and Iel-R (5'-CTA-CCT-TTGCAC-CAA-TTG-CTA-G-3') [21], which produce an amplicon of $502 \mathrm{bp}$, according to the following protocol: $60 \mathrm{~min}$ at $60^{\circ} \mathrm{C}, 2 \mathrm{~min}$ at $94^{\circ} \mathrm{C}, 40$ cycles of 45 s at $94^{\circ} \mathrm{C}, 45 \mathrm{~s}$ at $60^{\circ} \mathrm{C}$, and finally $7 \mathrm{~min}$ at $72^{\circ} \mathrm{C}$.

\subsection{In Vitro Maintenance of Hemocytes and WSSV Infection}

\subsubsection{Isolation and in Vitro Maintenance of the Hemocytes}

Hemolymph from 20 healthy shrimps $L$. vannamei $(50-150 \mu \mathrm{L}$ per shrimp) in intermolt-stage was extracted from the ventral sinus and mixed with ISS-EDTA in 1:3 ratio and allotted equally in experimental and control groups in $10 \mathrm{~mL}$ tubes. The hemocytes of the two $10 \mathrm{~mL}$ tubes (control and experimental) were separated from the hemolymph after centrifugation at $1000 \times g$ for $5 \mathrm{~min}$ and $4^{\circ} \mathrm{C}$. The supernatant was discarded, and the cell pellet was re-suspended gently with $500 \mu \mathrm{L}$ of ISS without EDTA, maintaining the samples at $4^{\circ} \mathrm{C}$. Both groups were divided into five aliquots of $100 \mu$ Land placed in 96-well sterile microplates (inertGrade $^{\mathrm{mm}}$ BrandTech $^{\circledR}$ Scientific), especially suited for cell cultures when adhesion is not desired.

\subsubsection{WSSV Infection in Isolated Hemocytes}

The experimental and control plates containing the hemocytes in ISS were challenged with $50 \mu \mathrm{L}$ of the WSSV inoculums and $50 \mu \mathrm{L}$ of ISS respectively. Plates were incubated at $29^{\circ} \mathrm{C}$ and $35 \mathrm{RPM}$ during $6 \mathrm{~h}$. Observations were performed at $30 \mathrm{~min}, 1,2,4$ and $6 \mathrm{~h}$ post-infection (h pi) and included: i) assessment of cell viability and ii) fixation of the samples to analyze the transcripts of WSSV.

\subsubsection{Assessment of Cell Viability}

Once finished the observation times, hemocytes from the corresponding well were gently re-suspended with a micropipette to homogenize cells that could be attached to the bottom. Then, viability was evaluated through trypan blue stain exclusion method (Invitrogen $0.4 \%$ ), mixing $10 \mu \mathrm{L}$ of each sample with $10 \mu \mathrm{L}$ of the stain, and live and dead cells were counted twice/sample in an automated cell counter (Countess ${ }^{\mathrm{Tm}}$ Invitrogen). The number of viable cells was divided by the number of total cell per 100 and expressed as a percentage of viability= [(live cells) $/($ total cells $)] \times 100$.

\subsubsection{Hemocytes Samples Fixation and RNA Isolation}

The remaining cells from each well were fixed with TRIzol ${ }^{\circledR}$ Reagent (Invitrogen) for RNA isolation following the manufacturer's recommendations, and recuperation of total well content was ensured after revision of the plates with an optical microscope. Total RNA concentration was measured with a Nano Drop 2000 spectrophotometer (Thermo-Scientific) at an A260/280nm ratio. RNA concentration was adjusted to $100 \mathrm{ng} / \mu \mathrm{L}$.

For all RNA samples, PCR reactions were performed to confirm they were 
DNA-free (data not shown), evaluating the Iel gene using the IQ SYBR ${ }^{\circledR}$ green supermix kit (Biorad) and the primers Iel-F and Iel-R [21] with the same amplification protocol described above.

\subsection{WSSV Transcripts Detection Using RT-PCR}

For the absolute quantification of WSSV by RT-PCR, the $502 \mathrm{bp}$ amplicon of the $I e l$ gene was amplified using DNA from the inoculum as a template and cloned into the CloneJET PCR Cloning Kit (Thermo Scientific ${ }^{\mathrm{m}}$ ), according to the manufacturer's instructions. The recombinant plasmid was sequenced, quantified and used as a template to perform serial dilutions with known copy numbers ranging from $2 \times 10^{6}$ to 20 copies $\mu \mathrm{L}^{-1}$. cDNA was synthesized from experimental and control RNA samples using the iScript ${ }^{\mathrm{Tx}}$ (Biorad) system, following manufacturer's recommendations. Reactions of RT-PCR were performed to detect the $I e 1$ gene using the IQ $S \mathrm{BR}^{\circledR}$ green supermix kit (Biorad) and the primers $I e 1-\mathrm{F}$ and Iel-R [21] with the same amplification protocol described above. Amplification specificity was assessed by melting curve analysis.

\subsection{Detection of Uninfected and WSSV Infected Hemocytes Using SEM}

The effect of WSSV was assessed at the end of the experiment ( $6 \mathrm{~h} \mathrm{pi}$ ). Hemocytes were analyzed by scanning electron microscopy (SEM). A sub-sample of hemocytes were fixed with a fixation solution (3\% glutaraldehyde and $0.1 \mathrm{M}$ sodium cacodylate), washed two times with saline phosphate buffer $(137 \mathrm{mM}$ $\mathrm{NaCl}, 2.7 \mathrm{mM} \mathrm{KCl}, 4.3 \mathrm{mM} \mathrm{Na} \mathrm{HPO}_{4}, 1.47 \mathrm{mM} \mathrm{KH}_{2} \mathrm{PO}_{4}, \mathrm{pH}$ 7.4), washed one more time with distilled water and dehydrated for intervals of $15 \mathrm{~min}$ in ethanol series (30\%, 50\%, 70\%, 90\%, and 100\%) [22]. The samples were dropped on a 13 $\mathrm{mm}$ Thermanox Plastic ${ }^{\circledR}$ coverslips (Nunc) pretreated with $0.2 \%$ gelatin and finally dried using a critical point drier (Quorum ${ }^{\circledR}$, model K850) and coated with gold-palladium using an ion sputter coater (Quorum, Q150R ES). The hemocytes were observed under the scanning electron microscope (FESEM Jeol $7600 \mathrm{~F}$ ) with $25 \mathrm{kV}$ at $2500 \mathrm{X}$.

\subsection{Statistical Analyses}

For each experiment, three replicates were performed. The data obtained from the three replicates, including cell viability and viral charge, were averaged. This study consisted of repeated measures over time, which implies that measures were dependent. Consequently, a generalized least squares (GLS) model was used to evaluate the prognosis of the viral load against time post infection from both groups. The general model was expressed as $y=\chi_{0}+\varepsilon$, where $y$ is the (n) values of the viral load observed at each time. $\mathrm{X}$ is a matrix of dimension $\mathrm{n} \times$ 2 , the first column consists of only ones (for the intercept) and the second variable is the time effect. $\beta$ contains the intercept $\alpha$, and the coefficient $\beta_{1}$. $\mathcal{E}$ represents the residual error. The residual error is normally distributed with 
mean 0 and variance-covariance structure contained in a matrix $\Omega, \mathcal{E} \sim N\left(0, \sigma^{2}\right.$ $\Omega$ ). For the covariance structure of the repeated measures (individuals), four possible models were examined; 1) compound symmetry, 2) completely unstructured, 3) autoregressive with equal variances, and 4) autoregressive with unequal variances [23]. Finally, the model with the lowest Akaike Information Criterion (AIC) value was selected.

The generalized estimating equations (GEE) were used to evaluate the effects of cell viability and time effects. For this, cell viability was assumed to follow a binomial distribution. GEE allow for the use of a correlation matrix structure which takes into account the lack of independence from the same cluster (each group of wells). The conditional mean $\mathrm{E}\left(\mathrm{Y}_{i t} \mid \mathrm{X}_{i t}\right)=\mu_{i t}$ is related to independent variables through a link function $\mathrm{g}\left(\mu_{i t}\right)=\mathrm{X}_{i t} \beta$. Cell viability corresponds to the well $i$ in time $t$. Variance structure of $\mathrm{Y}_{i t}$ is given by $\operatorname{var}\left(\mathrm{Y}_{i t} \mid \mathrm{X}_{i t}\right)=\mu_{i t}\left(1-\mu_{i t}\right)$ for proportional data [23]. An auto-regressive correlation structure was assumed because it was also assumed the association between points to be time dependent.

The GLS was performed using the nlme package [24] and the GEE using the gee package, both implemented in R, Core Team.

\section{Results}

\subsection{Screening of Viral Pathogens in L. vannamei}

All shrimps tested negative for WSSV, TSV, IHHNV, YHV, and IMNV (data not shown), meaning all shrimps were free of viral presence.

\subsection{Viral Inoculum Preparation and Inoculum's Infectivity}

The WSSV viral load in the inoculum was of 600 copies/ $\mu$ l. The five shrimps $L$. vannamei injected with $50 \mu \mathrm{L}$ of the inoculum $(\approx 30,000$ viral copies) began to show clinical signs of the disease after $24 \mathrm{hpi}$; i.e. a sudden reduction of food consumption, lethargy, loose cuticle and reddish coloration. The presence of viral Iel transcripts in their hemocytes confirmed the infection by WSSV (data not shown).

\subsection{Hemocytes Viability}

Cell viability in the infected group was of $89.60 \%( \pm 1.58)$ at $30 \mathrm{~min}$ pi, 84.20 $( \pm 2.15)$ at $1 \mathrm{~h} \mathrm{pi}, 83.30( \pm 7.89)$ at $2 \mathrm{~h} \mathrm{pi}, 61.70( \pm 14.22)$ at $4 \mathrm{~h} \mathrm{pi}$, and 34.60 $( \pm 11.06)$ at $6 \mathrm{~h}$ pi. In the control group (uninfected) it was of $89.08 \%( \pm 0.82)$ at $30 \mathrm{~min} \mathrm{pi,} 86.86 \%( \pm 1.79)$ at $1 \mathrm{~h} \mathrm{pi}, 84.59 \%( \pm 3.89)$ at $2 \mathrm{~h} \mathrm{pi,} 62.57 \%( \pm 10.78)$ at $4 \mathrm{~h} \mathrm{pi}$, and $45.00( \pm 10.58)$ at $6 \mathrm{~h}$ pi.

In vitro viability of the control and the infected groups showed no significant differences (Table 1 top part). The viability showed a decreasing tendency as time progressed, showing the lowest proportion of viable cells at $6 \mathrm{~h}$ pi. Notice that coefficients of $1 \mathrm{~h}$ pi with respect to $0.5 \mathrm{~h}$ pi, and $2 \mathrm{~h}$ pi with respect to $1 \mathrm{~h}$ pi, were no statistically significative different, while coefficients for $4 \mathrm{~h}$ pi with 
respect to $2 \mathrm{~h}$ pi and $6 \mathrm{~h}$ pi with respect to $4 \mathrm{~h}$ pi were statistically different (Table 1 top part). However, the viability rate in control group was never less than $40 \%$ (Figure 1(a)).

\subsection{Viral Load of Hemocytes Maintained in ISS}

The number of viral copies/cell was estimated in both groups by using a quanti-

Table 1. Coefficients from the generalized estimating equations applied to the proportion of viable cells (top part). Coefficients from the generalized least squares applied to the number of viral replicates per cell viable (bottom part).

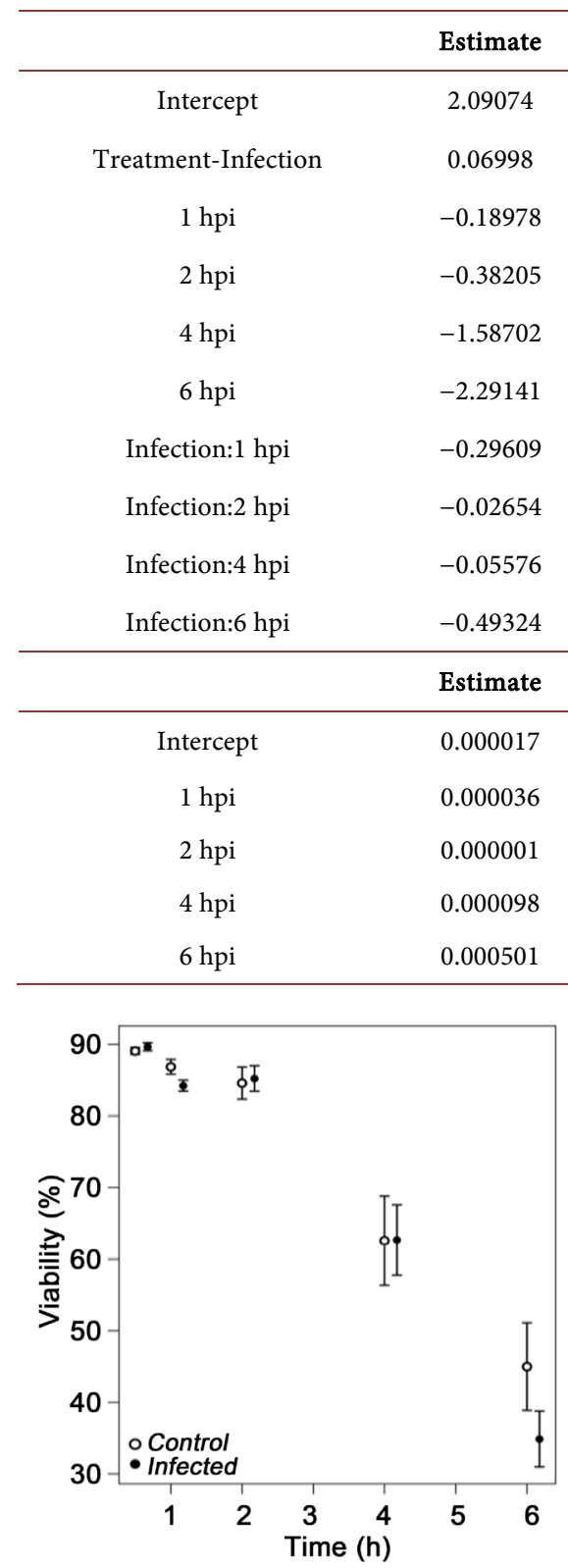

(a)

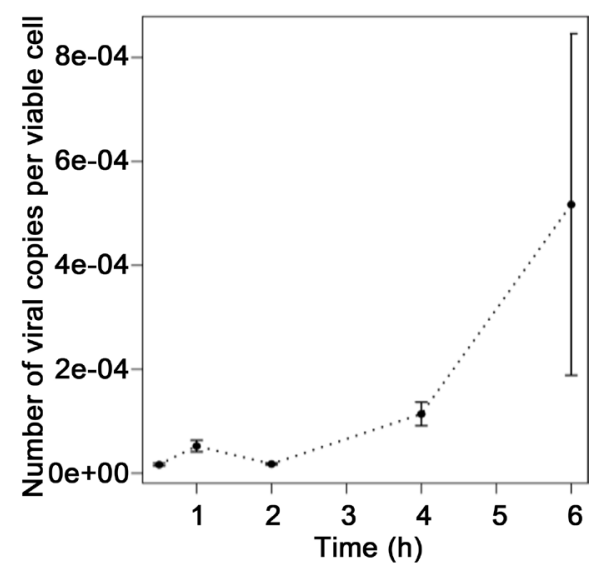

(b)

Figure 1. Hemocytes in ISS infected with WSSV. (a) Mean value of cell viability for control and infected groups; (b) Mean value of the number of viral replicates per viable cell in the infected group. Bars are standard errors. 
fication curve by RT-PCR. The total viral load was $82.88( \pm 39.89)$ viral copies at $30 \mathrm{~min} \mathrm{pi,} 257.62( \pm 191.80)$ viral copies at $1 \mathrm{~h} \mathrm{pi}, 78.20( \pm 20.30)$ viral copies at 2 hpi, $343.82( \pm 164.77)$ viral copies at $4 \mathrm{~h} \mathrm{pi}$, and $233.85( \pm 229.71)$ viral copies at 6 $\mathrm{h}$ pi. The total number of viral copies was divided into the number of live cells in Figure 1(b). Only in the infected group, the $I e 1$ gene was up-regulated during all the experiment.

The viral load's observations showed positive coefficients during the complete kinetics, being the highest at $6 \mathrm{~h}$ pi (Table 1 bottom part). The standard error at 6 hpi was the highest (Table 1 bottom part). From these observations, we could confirm that in this group the virus was replicating along the WSSV infection kinetics, while hemocytes in the ISS negative control group were free of WSSV contamination.

\subsection{Cytopathic Effect of WSSV on Hemocytes}

Granular cells from the uninfected group showed membrane integrity, spherical shape, the presence of granules and a size of $6.8 \mu \mathrm{m}$ in diameter (Figure 2(a) and (Figure 2(c)). In contrast, cells isolated from WSSV infected hemocytes
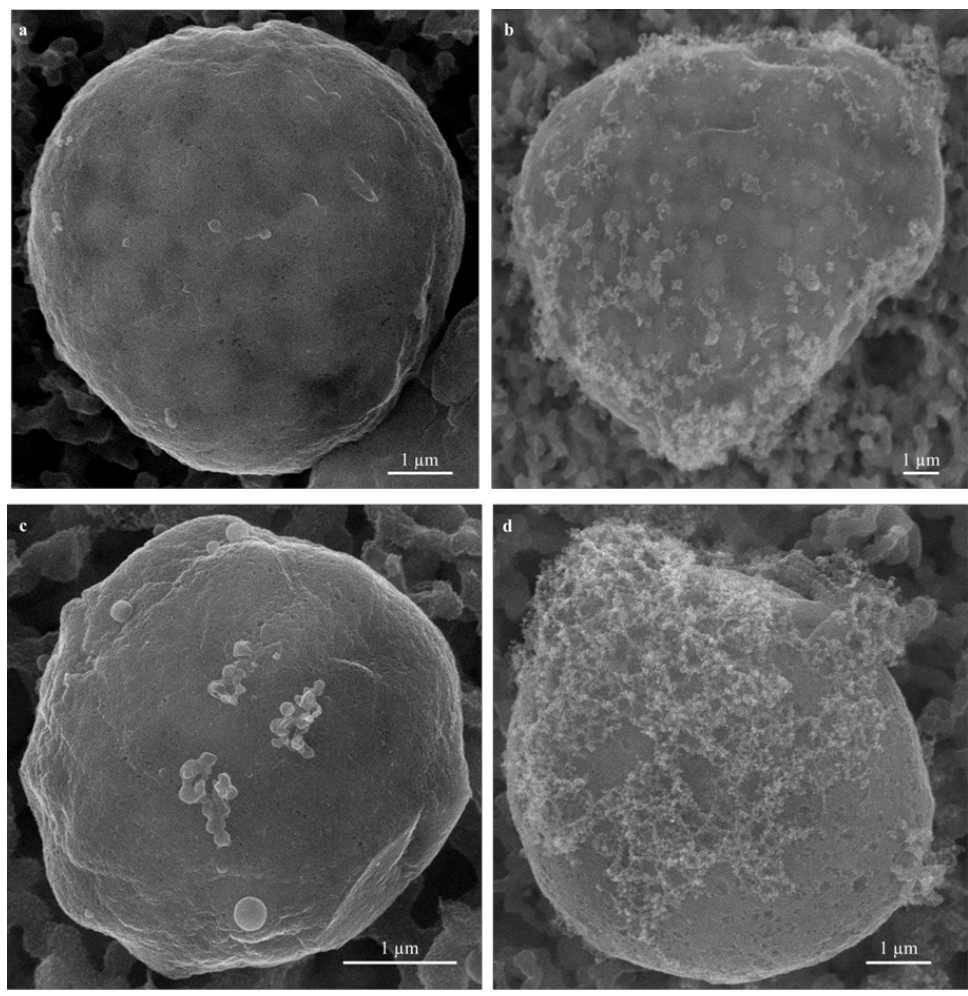

Figure 2. Electron micrographs of gold-palladium coated granular hemocyte from both WSSV infected and control ISS conditions. (a) Uninfected hemocyte showing a spherical shape and a size of $6.8 \mu \mathrm{m}$ in diameter; (b) WSSV infected hemocyte showing disrupted integrity and irregular shape and a size of 11.6 in length and 14.8 in width; (c) Uninfected hemocyte showing a spherical shape and a size of $4 \mu \mathrm{m}$ in diameter; (d) WSSV infected hemocyte showing disrupted integrity and irregular shape and dense content surrounding the cell, and a size of $7 \mu \mathrm{m}$ in diameter. Scale bars $=1 \mu \mathrm{m}$. The hemocytes were observed under a scanning electron microscope (FESEM Jeol 7600F) with $25 \mathrm{kV}$ at $2500 \mathrm{X}$. 
showed disrupted integrity, degranulation, irregular shape and a size of 11.6 in length and 14.8 in width ((Figure 2(b), (Figure 2(d)).

\section{Discussion}

In this decade, substantial effort has been done in order to establish a culture of crustacean's hemocytes, and significant achievements were obtained for in vitro manipulation of viral infections in different crustacean's species [11] [16] [18]. In this study, we proposed the use of ISS [20] to assess $L$. vannamei hemocytes viability and to detect viral replication during early stages of WSSV infection in this species.

Shrimps experimentally infected showed main signs of WSSV [25], therefore, the differential filtration during the inoculum preparation allowed the successful recovery of infective virions. This purification method process was also useful to prevent the hemocytes activation by remains of debris by separating them from the WSSV virions [26]. WSSV infection was also corroborated by amplification of the Iel gene in isolated hemocytes, an early-immediate transcription gene that plays a fundamental role in promoting viral replication and proliferation [21].

The hemocytes of $L$. vannamei were maintained up to 6 hpi in ISS during the in vitro infection. Results of viability, showed a similar decreasing pattern in both, the infected and the control groups at the end of the assays. Based on the statistical analyses, the ideal time of preservation of hemocytes goes between 0.5 and 2 hours. The hemocytes are highly reactive cells, and they start a process of controlled exocytosis when they are in contact with any strange pathogen like bacterial and fungi wall compounds, $\beta$-glucans or lipopolysaccharides, therefore, hemocyte population decreases rapidly [18]. In vivo, this action is compensated by the releasing of new hemocytes from the hematopoietic tissues into the hemolymph [27], whereas in in vitro conditions, hemocytes can react when they are attached to strange surfaces and their viability decreases over time with no compensation of new hemocytes. This had been marked as one of the main limitations of the implementation of suitable cell culture conditions [18]. The above mentioned reactivity could explain why the viability in this study was decreasing in both experimental and control groups, as well as some other factors such as that the media-solution in which the cells were suspended began to be insufficient to maintain the cells and the induction of apoptosis in the infected group.

In the infected hemocytes group, the Iel transcript was detected by RT-PCR as early as $30 \mathrm{~min}$ pi as well as during the kinetics. Although the viral load didn't show a linear proportion, our analysis showed that there is an increase in viral RNA (infection) each time with respect to the previous.

This Iel WSSV gene has been detected after 2 hpi, 4 hpi [28] and 6 hpi [29], but infection times of less than one hour have not been reported so far. In $L$. vannamei injected with WSSV was found that the early host transcriptome profile of hemocytes changed slightly in an early infection (5 hpi), while large tran- 
scriptional differences were identified at 48 hpi (late infection) of WSSV [30], showing the importance of studying early stages of the WSSV infection to comprehend the pathogeny of the disease.

The scanning electron microscopy analysis was used in this study to attest that the cytopathic effect was caused by WSSV and not by the manipulation of the cells. However, the cytopathic index was not performed because of the lack of enough samples.

The confirmation of infection in hemocytes by WSSV in times as short as 30 min generates interesting expectations to potential times for in vitro manipulation.

\section{Conclusion}

The detection of WSSV analyzed with the Iel gene, confirmed viral replication in hemocytes of $L$. vannamei as early as $30 \mathrm{~min}$ pi.

\section{Acknowledgements}

HPA was the recipient of a CONACYT scholarship (\#369654). This research was funded by the "Laboratorio de Referencia, Análisis y Diagnóstico de Sanidad Acuícola del Centro de Investigaciones Biológicas del Noroeste”(\#15789), and by the Project Conacyt-Ciencia Básica 2013 "Actividad antiinflamatoria y cicatrizante del Pepino de Mar (Isostichopus badionotus) en un modelo murino: caracterización de la actividad farmacológica y los mecanismos moleculares involucrados" (\# 221734). Special thanks are conveyed to Mrs. Ana Ruth Cristobal for helping with the SEM analyses at the Laboratorio Nacional de Biomateriales (LANBIOCINVESTAV-Mérida).

\section{Authorship and Conflicts of Interest Statement}

All authors agree with the content of the manuscript and there are no conflicts of interests between them.

\section{References}

[1] Briggs, M., Funge, S.S, Subasinghe, R.P. and Phillips, M. (2005) Introductions and Movement of Two Penaeid Shrimp Species in Asia and the Pacific. FAO. Fisheries Technical Paper. Food and Agriculture Organization of the United Nations. http://www.fao.org/documents/card/en/c/769f22e1-ccba-5e3d-a8ad-fd1380541789/

[2] Flegel, T.W. (1997) Major Viral Diseases of the Black Tiger Prawn (Penaeus monodon) in Thailand. Journal of Microbiology, 13, 433-442.

[3] Takahashi, Y., Itami, T., Kondo, M., Maeda, M., Fujii, R. and Tomonaga, S. (1994) Electron Microscopic Evidence of Bacilliform Virus Infection in Kuruma Shrimp (Penaeus japonicus). Fish Pathology, ISSN: 0388-788X.

[4] Wang, Y.G., Hassan, M.D., Shariff, M., Zamri, S.M. and Chen, X. (1999) Histopathology and Cytopathology of White Spot Syndrome Virus (WSSV) in Cultured Penaeus monodon from Peninsular Malaysia with Emphasis on Pathogenesis and the Mechanism of White Spot Formation. Diseases of Aquatic Organisms, 39, 1-11. https://doi.org/10.3354/dao039001 
[5] Jiravanichpaisal, P., Bangyeekhun, E., Söderhäll, K. and Söderhäll, I. (2001) Experimental Infection of White Spot Syndrome Virus in Freshwater Crayfish Pacifastacus leniusculus. Diseases of Aquatic Organisms, 47, 151-157. https://doi.org/10.3354/dao047151

[6] Wang, Y.T., Liu, W., Seah, J.N., Lam, C.S., Xiang, J.H. and Korzh, V. (2002) White Spot Syndrome Virus (WSSV) Infects Specific Hemocytes of the Shrimp Penaeus merguiensis. Diseases of Aquatic Organisms, 52, 249-259. https://doi.org/10.3354/dao052249

[7] Roch, P. (1999) Defense Mechanisms and Disease Prevention in Farmed Marine Invertebrates. Aquaculture, 172, 125-145. https://doi.org/10.1016/S0044-8486(98)00439-6

[8] Tepass, U., Fessler, L., Aziz, A. and Hartenstein, V. (1994) Embryonic Origin of Hemocytes and Their Relationship to Cell Death in Drosophila. Development, 120 , 1829-1837.

[9] Söderhäll, K. and Cerenius, L. (1992) Crustacean Immunity. Annual Review of Fish Diseases, 2, 3-23. https://doi.org/10.1016/0959-8030(92)90053-Z

[10] Söderhäll, I. (2016) Crustacean Hematopoiesis. Developmental and Comparative Immunology, 58, 129-141. https://doi.org/10.1016/j.dci.2015.12.009

[11] Li, F., Li, M., Ke, W., Ji, Y., Bian, X. and Yan, X. (2009) Identification of Three Immediate-Early Genes of White Spot Syndrome Virus. Virology, 385, 267-274. https://doi.org/10.1016/j.virol.2008.12.007

[12] Wu, J., Li, F., Huang, J., Xu, L. and Yang, F. (2015) Crayfish Hematopoietic Tissue Cells But Not Hemocytes Are Permissive for White Spot Syndrome Virus Replication. Fish \& Shellfish Immunology, 43, 67-74. https://doi.org/10.1016/j.fsi.2014.12.013

[13] Ellender, R.D., Najafabadi, A.K. and Middlebrooks, B.L. (1992) Observations on the Primary Culture of Hemocytes of Penaeus. Journal of Crustacean Biology, 12, 178-185. https://doi.org/10.2307/1549072

[14] Chen, S.N. and Wang, C.S. (1999) Establishment of Cell Culture Systems from Penaeid Shrimp and Their Susceptibility to White Spot Disease and Yellow Head Viruses. Methods in Cell Science: An Official Journal of the Society for In Vitro Biology, 21, 199-206. https://doi.org/10.1023/A:1009885929335

[15] Jiang, Y.S., Zhan, W.B., Wang, S.B. and Xing, J. (2006) Development of Primary Shrimp Hemocyte Cultures of Penaeus chinensis to Study White Spot Syndrome Virus (WSSV) Infection. Aquaculture, 253, 114-119. https://doi.org/10.1016/j.aquaculture.2005.07.045

[16] Li, C. and Shields, J.D. (2007) Primary Culture of Hemocytes from the Caribbean Spiny Lobster, Panulirus argus, and Their Susceptibility to Panulirus argus Virus 1 (PaV1). Journal of Invertebrate Pathology, 94, 48-55. https://doi.org/10.1016/j.jip.2006.08.011

[17] Jose, S., Mohandas, A., Philip, R. and Bright Singh, I.S. (2010) Primary Hemocyte Culture of Penaeus monodon as an In Vitro Model for White Spot Syndrome Virus Titration, Viral and Immune Related Gene Expression and Cytotoxicity Assays. Journal of Invertebrate Pathology, 105, 312-321. https://doi.org/10.1016/j.jip.2010.08.006

[18] Dantas-Lima, J.J., Corteel, M., Oanh, D.T.H., Bossier, P., Sorgeloos, P. and Nauwynck, H.J. (2012) Development of Two Haemocyte Culture Systems (in Attachment and in Suspension) for Shrimp Immunity Studies. Aquaculture, 366-367, 17-26. https://doi.org/10.1016/j.aquaculture.2012.08.032 
[19] Gracia-Valenzuela, M.H., Coronado-Molina, D., Hernández-López, J. and GollasGalván, T. (2009) A Simple Method for Purifying the White Spot Syndrome Virus Using Ultrafiltration. Aquaculture Research, 40, 737-743. https://doi.org/10.1111/j.1365-2109.2008.02155.x

[20] Vargas-Albores, F., Guzmán, M.A. and Ochoa, J.L. (1993) An Anticoagulant Solution for Haemolymph Collection and Prophenoloxidase Studies of Penaeid Shrimp (Penaeus californiensis). Comparative Biochemistry and Physiology Part A: Physiology, 106, 299-303. https://doi.org/10.1016/0300-9629(93)90516-7

[21] Liu, W.J., Chang, Y.S., Wang, C.H., Kou, G.H. and Lo, C.F. (2005) Microarray and RT-PCR Screening for White Spot Syndrome Virus Immediate-Early Genes in Cycloheximide-Treated Shrimp. Virology, 334, 327-341. https://doi.org/10.1016/j.virol.2005.01.047

[22] Manachini, B., Arizza, V., Parrinello, D. and Parrinello, N. (2011) Hemocytes of Rhynchophorus ferrugineus (Olivier) (Coleoptera: Curculionidae) and Their Response to Saccharomyces cerevisiae and Bacillus thuringiensis. Journal of Invertebrate Pathology, 106, 360-365. https://doi.org/10.1016/j.jip.2010.12.006

[23] Zuur, A.F., Ieno, E.N., Walker, N., Saveliev, A.A. and Smith, G.M. (2009) Mixed Effects Models and Extensions in Ecology with R. Springer New York, Statistics for Biology and Health, New York. https://doi.org/10.1007/978-0-387-87458-6

[24] Pinheiro, J., Bates, D., DebRoy, S., Sarkar, D. and Team, R.D.C. (2012) Nlme: Linear and Nonlinear Mixed Effects Models. R Package Version, 31-104.

[25] Durand, S., Lightner, D.V., Redman, R.M. and Bonami, J.R. (1997) Ultrastructure and Morphogenesis of White Spot Syndrome Baculovirus (WSSV). Disease of Aquatic Organisms, 29, 205-211. https://doi.org/10.3354/dao029205

[26] Hodinka, R.L. and Kaiser, L. (2013) Is the Era of Viral Culture over in the Clinical Microbiology Laboratory? Journal of Clinical Microbiology, 51, 2-8. https://doi.org/10.1128/JCM.02593-12

[27] Söderhäll, I., Bangyeekhun, E., Mayo, S. and Söderhäll, K. (2003) Hemocyte Production and Maturation in an Invertebrate Animal; Proliferation and Gene Expression in Hematopoietic Stem Cells of Pacifastacus leniusculus. Developmental \& Comparative Immunology, 27, 661-672. https://doi.org/10.1016/S0145-305X(03)00039-9

[28] Tsai, M.-F., Yu, H.-T., Tzeng, H.-F., Leu, J.-H., Chou, C.-M. and Huang, C.-J. (2000) Identification and Characterization of a Shrimp White Spot Syndrome Virus (WSSV) Gene That Encodes a Novel Chimeric Polypeptide of Cellular-Type Thymidine Kinase and Thymidylate Kinase. Virology, 277, 100-110. https://doi.org/10.1006/viro.2000.0597

[29] Lan, Y., Xu, X., Yang, F. and Zhang, X. (2006) Transcriptional Profile of Shrimp White Spot Syndrome Virus (WSSV) Genes with DNA Microarray. Archives of Virology, 151, 1723-1733. https://doi.org/10.1007/s00705-006-0751-X

[30] Xue, S., Liu, Y., Zhang, Y., Sun, Y., Geng, X. and Sun, J. (2013) Sequencing and De Novo Analysis of the Hemocytes Transcriptome in Litopenaeus vannamei Response to White Spot Syndrome Virus Infection. PLOS ONE, 8, e76718.

https://doi.org/10.1371/journal.pone.0076718 